\title{
Sensitivity of CESEE countries' export of differentiated products to exchange rate changes
}

\author{
Article history: \\ Received: 3 July 2020 \\ Sent for revision: 7 October 2020 \\ Received in revised form: 14 October 2020 \\ Accepted: 20 October 2020 \\ Available online: 4 December 2020
}

\begin{abstract}
The research aims to examine the effects of exchange rate changes on the value of bilateral export of differentiated products in the selected CESEE countries, while controlling the impact of traditional gravity variables. Identifying the determinants that affect the export of high value-added products is of particular importance for this group of countries, while analyzing the effects of exchange rate changes is a contribution to the previous researches. In order to comprehensively understand the relationship between the observed variables, a quantile panel regeression was used to estimate the gravity equation. Examining the heterogeneity of the impact of exchange rate changes and other selected trade factors along the export distribution is another contribution of the paper, given that bilateral trade researches are usually based on assessing the average impact. The results indicate that the CESEE countries' export of differentiated products is significantly influenced by exchange rate changes. Exchange rate volatility has a negative impact, which grows at higher levels of
\end{abstract}

\footnotetext{
${ }^{1}$ Faculty of Economics, University of Belgrade, aleksandra.djordjevic@ekof.bg.ac.rs
} Industrija, Vol.48, No.3, 2020 
export. The heterogeneity of the impact depending on export level was also confirmed for other determinants discussed in the paper.

Keywords: exchange rate volatility, exchange rate misalignment, export, gravity model, quantile panel regression

\section{Osetljivost izvoza diferenciranih proizvoda CESEE zemalja na promene deviznih kurseva}

Apstrakt: Istraživanje nastoji da ispita efekte promena deviznih kurseva na vrednost bilateralnog izvoza diferenciranih proizvoda izabranih CESEE zemalja, uz kontrolisanje uticaja standardnih gravitacionih varijabli. Identifikovanje determinanti koje utiču na izvoz proizvoda više dodate vrednosti je za ovu grupaciju zemalja od posebne važnosti, pri čemu analiziranje efekata koji promene deviznih kurseva imaju na kretanje izvoza ove vrste proizvoda predstavlja doprinos dosadašnjim istraživanjima. U cilju sveobuhvatnog razumevanja veze između posmatranih varijabli za ocenjivanje gravitacione jednačine korišćena je kvantilna panel regresija. Ispitivanje heterogenosti uticaja promena deviznih kurseva i drugih izabranih faktora trgovine duž raspodele izvoza još jedan je od doprinosa ovog rada, s obzirom da se istraživanja bilateralne trgovine uobičajeno zasnivaju na ocenjivanju prosečnog uticaja. Dobijeni rezultati pokazuju da je izvoz diferenciranih proizvoda pod značajanim uticajem promena deviznih kurseva. Volatilnost deviznog kursa negativno se odražava na izvoz ovih proizvoda, pri čemu uticaj raste na višim nivoima izvoza. Heterogenost uticaja u zavisnosti od nivoa izvoza potvrđena je i u slučaju ostalih faktora razmatranih u ovom radu.

Ključne reči: volatilnost deviznog kursa, neuravnoteženost deviznog kursa, izvoz, gravitacioni model, kvantilna panel regresija

\section{Introduction}

Analysing the link between exchange rate changes and international trade became a highly relevant issue in the early 1970s, when a period of considerable exchange rate fluctuations occurred due to the collapse of the Bretton Woods System and the liberalization of capital flows. Numerous theoretical and empirical studies provided ambiguous conclusions regarding the relationship between exchange rate changes and bilateral trade. Most of the literature dealing with the topic is focused on developed countries, and trade is viewed at the aggregate level. However, considering the determinants of exports of developing countries and countries in transition is of immense 8 
importance, given the role that export plays in promoting their economic development. Moreover, sector-level analysis enables a clearer insight of the effects of selected determinants on export. The analysis of the determinants of exports of differentiated products in Central, Eastern and Southeastern European countries (CESEE) is the contribution to this discussion. This group of countries attaches great importance to the role of exchange rate in export growth (Kovačević, 2016), while emphasizing the need to increase the export of products characterized by a higher degree of added value, capital and technological intensity. Consequently, understanding the effects that exchange rates have on the export of differentiated products is important for adequate formulation of the economic policy measures of the analysed CESEE countries.

Having in mind the importance of considering the impact of exchange rates on the trade of CESEE countries, while the literature dealing with the issue is very modest (Kočenda \& Valachy, 2006; Égert \& Morales-Zumaquero, 2008), this research analyses the impact of volatility and misalignment of bilateral exchange rates on bilateral exports. The approach based on the simultaneous examination of both mentioned types of exchange rate changes is a recent trend in the literature, and the analysis of bilateral exports at the sectoral level, i.e. at a product group level, according to the recent literature (Péridy, 2003; Wang \& Barrett, 2007; Byrne, Darby \& MacDonald, 2008; Caglayan \& Di, 2010, etc.), should result in clearer identification of the effects. In order to comprehensively understand the impact of exchange rate changes and other selected determinants of international trade on export of differentiated products, the paper uses a quantile panel regression that allows assessing of the impact of the analysed determinants at different points of distribution of the dependent variable.

The theoretical framework of the conducted research is presented in the second part of the paper. The methodological basis of the analysis is discussed in Section 3, where the presentation of the model is accompanied with the analysis of the variables and the data used in the research. The results of applying quantile panel regression to the gravity model are presented and discussed in Section 4. The last section provides the concluding remarks.

\section{Literature review}

After the collapse of the Bretton Woods System, the impact of exchange rate volatility has been widely examined. In the extensive literature, both theoretical and empirical, it can be noticed that the impact of volatility on trade is ambiguous. In the first stages of examining the impact of volatility, researches which pointed out that this type of exchange rate change results in increased 
risk and transaction costs, consequently having negative effects on trade were dominant (Ethier, 1973; Clark, 1973; Baron, 1976; Hooper \& Kohlhagen, 1978; Cushman, 1983). The initial evidence of the disincentive effect of volatility on trade were questioned in subsequent studies that proved that volatility do not affect international trade (e.g., Bailey, Tavlas \& Obstfeld, 1989; Gagnon, 1993); or that it can even promote it (e.g. Brada \& Méndez, 1988; Franke, 1991; Sercu \& Vanhulle, 1992; McKenzie \& Brooks, 1997; McKenzie, 1998; Broll \& Eckwert, 1999), which was explained by the availability of financial instruments that enabled risk hedging (Ethier, 1973), the degree of risk aversion of a company (Giovannini, 1988) and the high amount of fixed costs in international trade (Franke, 1991). Ambiguous conclusions have also been present in the literature published since the beginning of the $21^{\text {st }}$ century. The impact of volatility on international trade ranges from negative (Rose, 2000; Péridy, 2003; IMF, 2004, etc.), through the absence of impact (e.g., Aristotelous, 2001; Tenreyro, 2007, Nicita, 2013, etc.), to the positive one (e.g., Kasman \& Kasman, 2005).

Besides volatility, exchange rate misalignment, as another type of exchange rate changes, should also be considered, in order to comprehensively understand the impact of exchange rate changes on international trade. Deviations of the exchange rate from the equilibrium level, as Côte (1994) points out, can be a greater source of uncertainty. More specifically, exchange rate misalignment sends the wrong price signals that can lead to inadequate resource allocation and changes in investment decisions, possibly resulting in detrimental consequences on international trade. Furthermore, misalignment can be linked to protectionist pressures. Examining the impact of misalignment on trade is a recent trend in the literature, given that analysing the effects of undervalued currencies on trading partners started being more important in the 2000s. Unlike volatility, the literature examining the impact of misalignment on international trade is less numerous. Considering the results of both theoretical (e.g. De Grauwe \& Verfaille, 1988; Hausmann, Pritchett \& Rodrik, 2005; Staiger \& Sykes, 2010; Berg \& Miao, 2010) and empirical literature (e.g. Razin \& Collins, 1999; Bernard \& Jensen, 2004; Byrne et al., 2008; Fang, Lai \& Miller, 2009; Nicita, 2013), it is not possible to identify an unambiguous impact of exchange rate misalignment on international trade.

Until the mid-2000s, most researches on the impact of exchange rates on export were based on aggregate data, whereby their results often suggested that exchange rates have no effect on trade. Researchers, looking for an explanation for the results that indicated the insensitivity of exports to exchange rate changes, pointed out that such a finding could be a consequence of socalled aggregation bias (Péridy, 2003). Namely, the observed aggregate effects can be nullified so that the impact of exchange rate changes on export is not 
significant. Therefore, the recommendation of the recent literature is to use disaggregated data when analysing the impact of exchange rates on international trade. Thus, the existence of different export elasticities of certain product groups to exchange rate changes is taken into account, which results in stronger evidence regarding the link between exchange rates and export (McKenzie, 1998; Égert \& Morales-Zumaquero, 2008; Byrne et al., 2008; Auboini \& Ruta, 2013), providing clearer implications for economic policy.

Previous researches mainly used the gravity model when analysing the impact of exchange rates on export (Taglioni, 2002; IMF, 2004; Chit, Rizov \& Willenbockel, 2010; Wang, Wei \& Liu, 2010, Nicita, 2013, etc.), which is a standard method used in the empirical analysis of trade flows. However, the emphasis in previous researches was on examining the average impact, which provides only partial understanding of the relationship between the variables of interest. The importance of examining the heterogeneous impact of trade determinants depending on the level of trade was pointed out by Novy (2013) who emphasized that there is an asymmetry of the impact of trade costs on trade flows. Namely, more comprehensive conclusions can be obtained if the behaviour of the explanatory variable is monitored at different points of distribution of the dependent variable, which can be achieved by applying quantile regression. As Baltagi and Egger (2016) remark, quantile regression results in a detailed analysis of the overall distribution of bilateral trade, which is an issue that has not been sufficiently explored in either theoretical or empirical papers.

The diversity of the findings of the literature so far indicates that the impact of exchange rate changes on international trade still represents open and controversial issue, suggesting the importance and relevance of examining the phenomenon in every single case. Bearing in mind that the literature aimed at simultaneously analysing both types of exchange rate changes is still emerging, that conducting analysis on disaggregated data represents a recent trend in the literature, and that the literature dealing with this issue on the sample of CESEE countries is rather modest, the contribution of the research that is the subject of this paper is multiple.

\section{Research methodology}

The analysis of the determinants of international trade is usually based on the assumption of constant elasticity of trade flows to trade costs. Given that it is reasonably to expect that the impact varies depending on the intensity of the trade, Novy (2013) and Baltagi and Egger (2016) criticize the assumption of constant elasticity and emphasize the importance of analyzing the 
heterogeneity of impacts. These two studies represent the methodological framework for this research.

In the research being the subject of this paper, the examination of heterogenous impact is conducted at the sectoral level (according to Novy (2013) recommendation), using quantile regression as the methodology whose multiple advantages in evaluating the gravity model are pointed out by Baltagi and Egger (2016). In addition to examining the heterogenous impact of standard gravity variables, this research examines the effects of exchange rates with special interest, for which analysis by using quantile regression, to our knowledge, has not been represented in the literature so far.

The research is based on panel data of bilateral export of differentiated products from the selected CESEE countries, in the period from 2006 to 2016. Differentiated products in this study are products that belong to categories 4 (Capital goods (except transport equipment) and parts and accessories thereof) and 5 (Transport equipment and parts and accessories thereof) of the BEC classification. These are products with high value added, modern technological characteristics, and a greater degree of differentiation, which makes them suitable for the research conducted in the paper. The application of the BEC classification is another contribution of this research with regard to the common application of SMTC. Starting from a wider set of countries in the CESEE region, 13 of them were selected for the initial sample: 9 countries from the Balkan region (Albania, Bosnia and Herzegovina, Bulgaria, Croatia, Macedonia, Montenegro, Romania, Serbia and Slovenia), the Czech Republic, Hungary and Poland, as CESEE countries which, according to the UNCTAD classification, belong to the group of emerging market countries, as well as Slovakia, which, due to common transition processes with some of the already mentioned countries, is usually involved in research related to the CESEE region. The choice of countries for the final sample was determined by the availability of data. The problem of missing data, typical for the disaggregated level analysis, is most pronounced in the case of exports of different product categories from Albania and Montenegro. Thus, the final sample includes 11 countries on the exporter side (Bosnia and Herzegovina, Bulgaria, Croatia, the Czech Republic, Hungary, Macedonia, Poland, Romania, Serbia, Slovakia and Slovenia) and 13 countries on the importer side (Albania, Bosnia and Herzegovina, Bulgaria, Croatia, the Czech Republic, Hungary, Macedonia, Montenegro, Poland, Romania, Serbia, Slovakia and Slovenia). 


\subsection{Model}

When defining the econometric framework, author adopts the approach developed by Baltagi and Egger (2016). Bilateral export from country $i$ to country $j\left(X_{i j}\right)$ has a deterministic $\left(X_{i j}^{d}\right)$ and a stochastic component $\left(U_{i j}\right)$ :

$$
X_{i j}=X_{i j}^{d} U_{i j}
$$

Deterministic component of the gravity model is typically defined as:

$$
X_{i j}^{d}=E_{i} T_{i j} M_{j}
$$

where $E_{i}$ represents the determinants related to the supply side (exporterspecific), $T_{i j}$ the costs of bilateral trade, and $M_{j}$ the determinants related to the demand side (importer-specific). Baltagi and Egger (2016) state that bilateral trade costs $T_{i j}$ can contain exporter-specific $\left(S_{i}^{E}\right)$, importer-specific $\left(S_{j}^{M}\right)$ and pair-specific $\left(S_{i j}^{P}\right)$ costs.

Baltagi and Egger (2016) focus only on examining the impact of pair-specific costs, with all other factors considered unobservable and assessed as a constant. Therefore, after applying the usual procedure of the logarithm transformation of the gravity equation, and after aggregating supply side determinants with the exporter-specific trade costs and demand side determinants with the importer-specific trade costs (which resulted in defining the scalars $\eta_{i} \equiv e_{i}+s_{i}^{E}$ and $\mu_{j} \equiv m_{j}+s_{j}^{M}$ ), Baltagi and Egger (2016) derive a model that allows estimating the parameters conditionally per quantile $(q)$ of the conditional distribution of $x_{i j}$ :

$$
x_{q, i j}=\eta_{q, i}+\left(\sum_{k=1}^{K} \beta_{q, k} d_{k, i j}\right)+\mu_{q, j}+u_{q, i j}
$$

The discussed model needs to be modified in accordance with the requirements of this research. Firstly, the time dimension ( $t$ ) should be included since the research is based on panel data. Furthermore, given author's interest in examining the impact of exporter-specific and importer-specific determinants, the model has to be modified by including $L$ supply side determinants $\left(E_{l, i t}\right)$ and $R$ demend sidy determinants $\left(M_{r, j t}\right)$ whose impact on export $\left(\beta_{l} \mathrm{i} \beta_{r}\right)$ is analysed. When considering trade costs, focus is on those thar are pair-specific (as in Baltagi and Egger (2016)), assuming that there are $K$ observable pairwise trade costs $\left(D_{k, i j t}\right)$ and estimating their impact on export $\left(\beta_{k}\right)$. Exporterspecific $\left(S_{i t}^{E}\right)$ and importer-specific $\left(S_{j t}^{M}\right)$ trade costs are not considered in this 
paper. They are unobservable, as pointed out by Baltagi and Egger (2016) and assumed to be constant.This leads to the following form of the deterministic compontent of the model:

$$
x_{i j t}^{d}=\sum_{l=1}^{L} \beta_{l} e_{l, i t}+\sum_{r=1}^{R} \beta_{r} m_{r, j t}+\sum_{k=1}^{K} \beta_{k} d_{k, i j t}
$$

According to Anderson and van Wincoop (2003), when evaluating the gravity equation, it is necessary to account for multilateral resistance (MRT), which, in this study, was done by including fixed effects (FE). Estimating FE models with quantile regression is a new approach in the econometric literature, which is being intensively developed. As Kato, Galvao Jr, \& Montes-Rojas (2012) claim, controlling heterogeneity through fixed effects, while simultaneously examining heterogenous impact by using quantile regression, represents a more flexible approach to panel data analysis compared to standardly applied estimation techniques.

Several different techniques for estimating FE models with quantile regression have been developed in the literature. Koenker (2004), Canay (2011), Galvao Jr (2011), Galvao, Lamarche, \& Lima (2013), Machado \& Silva (2019) are some of the authors who have developed this direction in the econometric literature. In the models developed so far, unobserved heterogeneity is controlled only by individual FE, which is one of the limitations of this type of analysis. However, the approach that involves controlling the MRT by including only individual FE (that are country-pair FE in the gravity model), has several advantages. This type of FE allows to control for unobserved heterogeneity specific to a particular pair of countries, resulting in more precise identification of the impact of those bilateral trade costs that are of particular interest for the research. Moreover, this type of FE makes it possible to deal with the endogeneity, which, as Tenreyro (2007) states, is particularly important when analysing the impact of exchange rates on export, while most of the previous studies assume that exchange rate changes are exogenous. As Tenreyro (2007) states, neglecting various factors that characterize trade between a particular pair of countries can result in inaccurate conclusions about the relationship between exchange rate changes and bilateral exports. Fixing their impact through pair FE results in more precise identification of the relationship between variable of interest and bilateral export. Furthermore, using only individual FE leads to the avoidance of the problems that arise in situations when exporter-time and importer-time FE are used in analyses of the impact of exchange rates on exports, as pointed out by IMF (2004) and Byrne et al. (2008). For these reasons, approach based on including only pair FE has been applied in relevant 
empirical papers dealing with the estimation of the gravity equation with $\mathrm{FE}$ using quantile regression, such as Figueiredo, Lima \& Schaur (2014) and Paniagua, Figueiredo \& Sapena (2015), among others.

Most techniques developed to estimate quantile regression models for panel data with FE are based on the assumption that $\mathrm{T} \rightarrow \infty$ when $\mathrm{N} \rightarrow \infty$, which often makes them inadequate (e.g. Canay, 2011; Machado \& Silva, 2019). However, the approach developed by Koenker (2004) was proposed in the literature when $N$ is relatively large in relation to $T$ (Marino \& Farcomeni, 2015), which makes it suitable for the application in this research.

The empirical specification to evaluated bilateral export as a function of selected trade determinants using the Koenker (2004) procedure, is presented by the equation (5), based on the modification of Koenker (2004) specification in order to adapt it to the specifics of this research:

$$
Q_{l n X_{i j t}}\left(\tau \mid f_{i j t}\right)=\alpha_{i j}+f_{i j t}^{T} \beta(\tau)+u_{i j t}(\tau)
$$

The effects of the explanatory variables $\left(f_{i j t}\right)$ depend upon the quantile $(\tau)$. The individual effects $\left(\alpha_{i j}\right)$ in the Koenker (2004) model do not depend upon the quantile. This allows the evaluation of the impact of variables such as distance and common border, which cannot normally be evaluated in the presence of a pair FE. More specifically, in accordance with the previous discussion:

$$
\begin{aligned}
Q_{l n x_{i j t}}\left(\tau \mid e_{l i t}, m_{r j t}\right. & \left.d_{k i j t}\right) \\
= & \alpha_{i j}+\beta_{0}(\tau)+\sum_{l=1}^{L} \beta_{l} e_{l, i t}(\tau)+\sum_{r=1}^{R} \beta_{r} m_{r, j t}(\tau) \\
& +\sum_{k=1}^{K} \beta_{k} d_{k, i j t}(\tau)+u_{i j t}(\tau)
\end{aligned}
$$

Combining Baltagi and Egger (2016) and Konker (2004), the model can be presented as:

$$
\begin{gathered}
\ln X_{q, i j t}=\beta_{q, 0}+ \\
+\sum_{l=1}^{L} \beta_{q, l} e_{q, l i t}+\sum_{r=1}^{R} \beta_{q, r} m_{q, r j t}+\sum_{k=1}^{K} \beta_{q, k} d_{q, k i j t}+\alpha_{i j} \\
+u_{q, i j t}
\end{gathered}
$$

Equation (7) is estimated at 5 conventional quantiles: $0.1 ; 0.25 ; 0.5 ; 0.75$ and 0.9 , separately for the sector $(s)$ BEC 4 and BEC 5. 


\subsection{Variables and data}

A dependent variable is defined as the logarithmic value of the export of sector $s$, from country $i$ to country $j$ in a year $t$ in USD. The export data were collected from the UNCOMTRADE database. The problem of missing data (the export from Macedonia to all countries in the sample in 2008 and the export from Bosnia and Herzegovina, Bulgaria, Hungary, Macedonia and Romania to Montenegro in 2006) was solved by applying a new methodology developed within the IMF (Marini, Dippelsman \& Stanger, 2018). The data analysis of the dependent variable (presented in Tables 1 and 2 and Figure 1) confirm the adequacy of the application of quantile regression.

Table 1. Descriptive statistics of dependent variable for the period 2006-2016

\begin{tabular}{|c|c|c|c|c|c|c|c|}
\hline $\begin{array}{c}\text { Dependent } \\
\text { variable }\end{array}$ & Average & $\begin{array}{c}\text { Standard } \\
\text { deviation }\end{array}$ & Minimum & Median & Maximum & Skewness & Kurtosis \\
\hline BEC $4 \ln \boldsymbol{X}_{\boldsymbol{i j t}}$ & 17.0913 & 2.125896 & 9.965335 & 17.22592 & 21.62874 & -0.2820203 & 2.862233 \\
\hline BEC $5 \ln \boldsymbol{X}_{\boldsymbol{i j t}}$ & 16.62822 & 2.519866 & 5.303305 & 16.80012 & 21.70398 & -0.3951087 & 2.960984 \\
\hline
\end{tabular}

Source: Author's calculations.

Table 2. The results of testing the normality of the distribution of dependent variable by product category

\begin{tabular}{|c|c|c|c|c|}
\hline \multirow[b]{2}{*}{$\begin{array}{c}\text { Dependent } \\
\text { variable }\end{array}$} & \multicolumn{3}{|c|}{ Skewness and kurtosis test } & \multirow{2}{*}{$\begin{array}{c}\text { Shapiro-Wilk W test } \\
\text { p-value }\end{array}$} \\
\hline & $\begin{array}{c}\text { p-value } \\
\text { (skewness) }\end{array}$ & $\begin{array}{c}\text { p-value } \\
\text { (kurtosis) }\end{array}$ & $\begin{array}{c}\text { p-values (skewness and } \\
\text { kurtosis) }\end{array}$ & \\
\hline BEC $4 \ln X_{i j t}$ & 0.0000 & 0.2876 & 0.0001 & 0.0000 \\
\hline BEC $5 \ln X_{i j t}$ & 0.0000 & 0.8287 & 0.0000 & 0.0000 \\
\hline
\end{tabular}

Source: Author's calculations.

Figure 1. Distribution of the dependent variable by quantiles
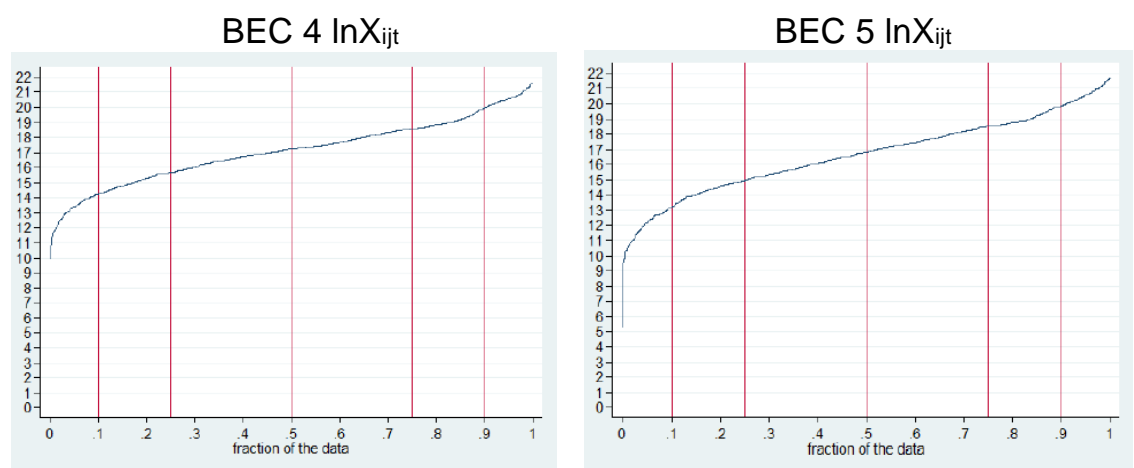

Source: Author's calculations

16

Industrija, Vol.48, No.3, 2020 
The values of skewness and kurtosis, the results of testing the normality of the distribution, as well as the graphical representation of the distribution function by quantiles, indicate the presence of extreme values and deviation from the normal distribution of the dependent variable, which stimulates the application of quantile regression, considered to be a favourable estimation method in these situations.

The determinants whose impact on export is examined are presented in Table 3 . They are classified into 3 basic groups, in accordance with the methodological framework explained in section 3.1.

Table 3. Overview of explanatory variables

\begin{tabular}{|c|l|l|}
\hline \multicolumn{1}{|c|}{ Variable } & \multicolumn{1}{|c|}{ Approximation } & \multicolumn{1}{c|}{ Source } \\
\hline Supply side determinants $\left(\boldsymbol{e}_{l, i t}\right)$ & \multicolumn{1}{|c|}{} \\
\hline Exporter GDP $\left(Y_{i t}\right)$ & $\begin{array}{l}\text { The natural logarithm of } \\
\text { GDP (in mil USD) }\end{array}$ & IMF WEO \\
\hline Exporter GDP per capita $\left(\frac{Y_{i t}}{L_{i t}}\right)$ & $\begin{array}{l}\text { The natural logarithm of } \\
\text { GDP per capita (in USD) }\end{array}$ & IMF WEO \\
\hline Demend side determinants $\left(\boldsymbol{m}_{r, j t}\right)$ & $\begin{array}{l}\text { The natural logarithm of } \\
\text { GDP (in mil USD) }\end{array}$ & IMF WEO \\
\hline Importer GDP $\left(Y_{j t}\right)$ & $\begin{array}{l}\text { The natural logarithm of } \\
\text { GDP per capita (in USD) }\end{array}$ & IMF WEO \\
\hline Importer GDP per capita $\left(\frac{Y_{j t}}{L_{j t}}\right)$ & Artificial variable 1/0 & CEPII \\
\hline Trade costs $\left(\boldsymbol{d}_{\boldsymbol{k}, i j t}\right)$ & $\begin{array}{l}\text { The natural logarithm of } \\
\text { geographical distance }\end{array}$ & CEPII \\
\hline Common border $\left(C B_{i j}\right)$ & $\begin{array}{l}\text { The measure based on } \\
\text { standard deviation }\end{array}$ & $\begin{array}{l}\text { The author's } \\
\text { calculations }\end{array}$ \\
\hline Distance $\left(D_{i j}\right)$ & $\begin{array}{l}\text { Rodrik's (2008) } \\
\text { undervaluation index }\end{array}$ & $\begin{array}{l}\text { The author's } \\
\text { calculations }\end{array}$ \\
\hline Bilateral exchange rate volatility $\left(V O L_{i j t}\right)$ \\
\hline $\begin{array}{l}\text { Bilateral exchange rate } \\
\text { misalignment }\left(M I S_{i j t}\right)\end{array}$ &
\end{tabular}

Source: Author's presentation

In addition to the exporter and importer GDP, as the determinants on the supply and demand side are also included the exporter and importer GDP per capita, which is the approach recommended in the literature when the analysis is based on disaggregated data (Bergstrand, 1985, 1989). Trade costs include common border and distance, as standard gravity variables, but also bilateral exchange rate volatility and misalignment, as variables of particular interest in this study.

Bilateral exchange rate volatility was calculated as the standard deviation of the first-difference of the logarithm of the bilateral real exchange rate $\left(e_{i j t}\right)$ calculated for a period of one year based on monthly data (Brodsky, 1984; Kenen \& Rodrik, 1986; Rose, 2000; Tenreyro, 2007; Chit et al., 2010, etc.): 


$$
V O L_{i j t}=S t d \cdot d e v \cdot\left[\ln \left(e_{i j t, m}\right)-\ln \left(e_{i j t, m-1}\right)\right], m=1 \ldots 12 .
$$

The bilateral real exchange rates were calculated as a cross exchange rate based on the data of monthly exchange rates between the currencies of the countries in the sample and the US dollar from the IFS database.

The bilateral exchange rate misalignment was calculated based on Rodrik's (2008) three-step procedure for calculating the undervaluation index, which was adapted to the requirements of this research. As Rodrik (2008) underlines, the misalignment calculated in this way is comparable between countries and over time, which makes it convenient when analysing the impact of misalignment on trade, as is the case in Nicita (2013).

Descriptive statistics of independent variables are shown in Table 4. The values of the descriptive statistics of the standard gravity variables are in the expected intervals. The values of descriptive statistics of exchange rate volatility and misalignment, as the variables of special interest, are comparable with the values obtained in the literature.

Table 4. Descriptive statistics of the analysed determinants

\begin{tabular}{|l|r|r|r|r|}
\hline Variables & \multicolumn{1}{|c|}{ Average } & \multicolumn{1}{|c|}{ Standard deviation } & \multicolumn{1}{c|}{ Minimum } & \multicolumn{1}{c|}{ Maximum } \\
\hline $\ln Y_{i t}$ & 11.14871 & 1.07789 & 8.83346 & 13.20864 \\
\hline $\ln Y_{j t}$ & 10.76464 & 1.32541 & 7.90027 & 13.20864 \\
\hline $\ln \frac{Y_{i t}}{L_{i t}}$ & 9.21968 & 0.56600 & 8.06427 & 10.23222 \\
\hline $\ln \frac{Y_{j t}}{L_{j t}}$ & 9.10778 & 0.58483 & 7.99821 & 10.23222 \\
\hline $\ln D_{i j}$ & 6.26392 & & & \\
\hline $\ln C B_{i j}$ & 0.28788 & 0.53817 & 4.76512 & 7.47704 \\
\hline$V O L_{i j t}$ & 0.01220 & 0.45293 & 0 & 1 \\
\hline$M I S_{i j t}$ & -0.00066 & 0.00880 & 0 & 0.04167 \\
\hline
\end{tabular}

Source: Author's calculations and presentation

\section{Results and discussion}

Estimation of the impact of variables at different points of distribution of the dependent variable by using the Koenker (2004) procedure was performed in $\mathrm{R}$ software using the rqpd package: Regression Quantiles for panel data (longitudinal data). Results are presented in Table 5. 
Table 5. The results of estimating the gravity quantile regression model

\begin{tabular}{|c|c|c|c|c|c|c|c|c|c|c|}
\hline \multirow[b]{4}{*}{ Variables } & \multicolumn{5}{|c|}{ BEC 4} & \multicolumn{5}{|c|}{ BEC 5} \\
\hline & $q 0.1$ & q 0.25 & $q 0.5$ & q 0.75 & $q 0.9$ & $q 0.1$ & q 0.25 & $q 0.5$ & q 0.75 & q 0.9 \\
\hline & $(1)$ & (2) & (3) & (4) & (5) & $(1)$ & (2) & (3) & (4) & (5) \\
\hline & $\ln X_{i j t}$ & $\ln X_{i j t}$ & $\ln X_{i j t}$ & $\ln X_{i j t}$ & $\ln X_{i j t}$ & $\ln X_{i j t}$ & $\ln X_{i j t}$ & $\ln X_{i j t}$ & $\ln X_{i j t}$ & $\ln X_{i j t}$ \\
\hline $\ln Y_{i t}$ & $\begin{array}{c}0.903^{\star \star \star} \\
(0.079)\end{array}$ & $\begin{array}{c}0.811^{\star \star \star} \\
(0.057)\end{array}$ & $\begin{array}{c}0.786^{\star \star \star} \\
(0.054)\end{array}$ & $\begin{array}{c}0.772^{\star \star \star} \\
(0.056)\end{array}$ & $\begin{array}{c}0.721^{\star \star \star} \\
(0.060)\end{array}$ & $\begin{array}{c}1.162^{\star \star \star} \\
(0.087)\end{array}$ & $\begin{array}{c}1.097^{\star \star \star} \\
(0.068)\end{array}$ & $\begin{array}{c}1.054^{\star \star \star} \\
(0.063)\end{array}$ & $\begin{array}{c}0.973^{\star \star \star} \\
(0.062)\end{array}$ & $\begin{array}{c}0.959^{\star \star \star} \\
(0.089)\end{array}$ \\
\hline $\ln Y_{j t}$ & $\begin{array}{l}0.79^{\star \star \star} \\
(0.048)\end{array}$ & $\begin{array}{c}0.762^{\star \star \star} \\
(0.039)\end{array}$ & $\begin{array}{l}0.77^{\star \star \star} \\
(0.038)\end{array}$ & $\begin{array}{c}0.783^{\star \star \star *} \\
(0.040)\end{array}$ & $\begin{array}{c}0.746^{\star \star \star} \\
(0.049)\end{array}$ & $\begin{array}{c}0.923^{\star \star \star} \\
(0.066)\end{array}$ & $\begin{array}{l}0.86^{\star \star \star} \\
(0.053)\end{array}$ & $\begin{array}{c}0.804^{\star \star \star} \\
(0.045)\end{array}$ & $\begin{array}{c}0.805^{\star \star \star} \\
(0.044)\end{array}$ & $\begin{array}{c}0.778^{\star \star \star} \\
(0.057)\end{array}$ \\
\hline $\ln \left(Y_{i t} / L_{i t}\right)$ & $\begin{array}{l}1.094^{\star \star \star} \\
(0.110)\end{array}$ & $\begin{array}{l}1.028^{\star \star \star} \\
(0.086)\end{array}$ & $\begin{array}{l}0.973^{\star \star \star *} \\
(0.083)\end{array}$ & $\begin{array}{l}0.918^{* \star *} \\
(0.075)\end{array}$ & $\begin{array}{c}0.829^{\star \star \star} \\
(0.092)\end{array}$ & $\begin{array}{c}0.976^{\star \star \star *} \\
(0.172)\end{array}$ & $\begin{array}{c}0.781^{\star \star \star *} \\
(0.139)\end{array}$ & $\begin{array}{l}0.638^{* \star *} \\
(0.118)\end{array}$ & $\begin{array}{l}0.564^{\star \star \star} \\
(0.114)\end{array}$ & $\begin{array}{c}0.514^{\star \star \star} \\
(0.154)\end{array}$ \\
\hline $\ln \left(Y_{j t} / L_{j t}\right)$ & $\begin{array}{l}-0.167 \\
(0.123)\end{array}$ & $\begin{array}{l}-0.127 \\
(0.097)\end{array}$ & $\begin{array}{l}-0.101 \\
(0.091)\end{array}$ & $\begin{array}{l}-0.153^{\star} \\
(0.091)\end{array}$ & $\begin{array}{l}-0.084 \\
(0.109)\end{array}$ & $\begin{array}{c}0.174 \\
(0.163)\end{array}$ & $\begin{array}{c}0.212 \\
(0.131)\end{array}$ & $\begin{array}{l}0.245^{\star \star} \\
(0.118)\end{array}$ & $\begin{array}{l}0.233^{*} \\
(0.121)\end{array}$ & $\begin{array}{l}0.261^{\star} \\
(0.141)\end{array}$ \\
\hline $\ln D_{i j}$ & $\begin{array}{c}-0.924^{\star \star \star} \\
(0.119)\end{array}$ & $\begin{array}{c}-0.859^{\star \star \star} \\
(0.094)\end{array}$ & $\begin{array}{c}-0.781^{\star \star \star} \\
(0.088)\end{array}$ & $\begin{array}{c}-0.712^{\star \star \star} \\
(0.090)\end{array}$ & $\begin{array}{c}-0.657^{\star \star \star} \\
(0.105)\end{array}$ & $\begin{array}{c}-0.723^{\star \star \star} \\
(0.144)\end{array}$ & $\begin{array}{c}-0.648^{\star \star \star} \\
(0.143)\end{array}$ & $\begin{array}{c}-0.642^{\star \star \star} \\
(0.139)\end{array}$ & $\begin{array}{c}-0.601^{\star \star *} \\
(0.140)\end{array}$ & $\begin{array}{c}-0.466^{\star \star \star} \\
(0.160)\end{array}$ \\
\hline$C B_{i j}$ & $\begin{array}{c}1.309^{\star \star \star} \\
(0.107)\end{array}$ & $\begin{array}{l}1.235^{\star \star \star} \\
(0.094)\end{array}$ & $\begin{array}{c}1.189^{\star \star \star} \\
(0.084)\end{array}$ & $\begin{array}{l}1.222^{\star \star \star} \\
(0.082)\end{array}$ & $\begin{array}{l}1.163^{\star \star \star} \\
(0.093)\end{array}$ & $\begin{array}{c}1.314^{\star \star \star} \\
(0.154)\end{array}$ & $\begin{array}{c}1.228^{\star \star \star} \\
(0.133)\end{array}$ & $\begin{array}{c}1.084^{\star \star \star} \\
(0.125)\end{array}$ & $\begin{array}{c}0.953^{\star \star \star} \\
(0.127)\end{array}$ & $\begin{array}{c}0.915^{\star \star \star} \\
(0.153)\end{array}$ \\
\hline$V O L_{i j t}$ & $\begin{array}{c}-17.909^{\star \star \star} \\
(3.934)\end{array}$ & $\begin{array}{c}-20.165^{\star \star \star} \\
(2.582)\end{array}$ & $\begin{array}{c}-19.052^{\star \star \star} \\
(2.361)\end{array}$ & $\begin{array}{c}-20.507^{\star \star \star} \\
(2.951)\end{array}$ & $\begin{array}{c}-22.011^{\star \star \star} \\
(3.311)\end{array}$ & $\begin{array}{c}-20.026^{\star \star \star} \\
(5.115)\end{array}$ & $\begin{array}{c}-20.993^{\star \star \star} \\
(3.613)\end{array}$ & $\begin{array}{c}-20.383^{\star \star \star} \\
(3.052)\end{array}$ & $\begin{array}{c}-23.238^{\star \star \star} \\
(3.146)\end{array}$ & $\begin{array}{c}-29.612^{\star \star \star} \\
(4.718)\end{array}$ \\
\hline MIS $_{i j t}$ & $\begin{array}{l}-0.501^{\star} \\
(0.300)\end{array}$ & $\begin{array}{l}-0.456^{*} \\
(0.235)\end{array}$ & $\begin{array}{l}-0.405^{*} \\
(0.226)\end{array}$ & $\begin{array}{c}-0.465^{\star *} \\
(0.223)\end{array}$ & $\begin{array}{c}-0.518^{\star \star} \\
(0.246)\end{array}$ & $\begin{array}{c}0.23 \\
(0.406)\end{array}$ & $\begin{array}{c}0.243 \\
(0.348)\end{array}$ & $\begin{array}{c}0.117 \\
(0.296)\end{array}$ & $\begin{array}{c}0.027 \\
(0.280)\end{array}$ & $\begin{array}{c}0.049 \\
(0.307)\end{array}$ \\
\hline Constant & $\begin{array}{c}-4.938^{\star \star \star} \\
(1.187)\end{array}$ & $\begin{array}{c}-3.476^{\star \star \star} \\
(0.929)\end{array}$ & $\begin{array}{c}-3.242^{\star \star \star} \\
(0.836)\end{array}$ & $\begin{array}{c}-2.404^{\star \star \star} \\
(0.796)\end{array}$ & $\begin{array}{l}-1.293 \\
(0.896)\end{array}$ & $\begin{array}{c}-13.029^{\star \star \star} \\
(2.049)\end{array}$ & $\begin{array}{c}-10.221^{\star \star \star} \\
(1.512)\end{array}$ & $\begin{array}{c}-7.742^{\star \star \star} \\
(1.449)\end{array}$ & $\begin{array}{c}-5.884^{\star \star \star} \\
(1.498)\end{array}$ & $\begin{array}{c}-5.64^{\star \star \star} \\
(1.729)\end{array}$ \\
\hline $\begin{array}{l}\text { Number of } \\
\text { observations }\end{array}$ & 1452 & 1452 & 1452 & 1452 & 1452 & 1452 & 1452 & 1452 & 1452 & 1452 \\
\hline
\end{tabular}

The export of both product categories is positively influenced by supply and demand side factors, which is in line with the expectations. The high sensitivity of differentiated products to supply side factors is explained by the capital intensity of their production and its reliance on innovations and modern technology. The sensitivity of the export of differentiated products to demand side factors is explained by the increased demand for luxury products, products with high value-added and modern technological characteristics as importer GDP and GDP per capita grow. The positive effect of the supply side factors is most pronounced at the low level of export distribution, i.e. in the case of those country-pairs whose bilateral export is low. This implies that the growth of exporter GDP and GDP per capita would especially stimulate export to those countries with which trade, more precisely export, is at a low level. In other words, growth of exporter GDP and GDP per capita would contribute to the expansion of the export market of differentiated products, in the countries where the market share of the exporting country is low. The finding regarding the growing impact of demand side factors along the distribution of export of 
Transport equipment and parts and accessories thereof is rather interesting and can be explained by customer loyalty to a particular supplier, product and brand when it comes to the products belonging to this category. This result implies that the largest growth of the export of Transport equipment and parts and accessories thereof, which occurs as the result of growth in demand side factors, can be expected by the countries that have already achieved a large market share in the country whose GDP and GDP per capita are growing.

Distance and common border have a statistically significant effect on the export of both product categories at all considered export levels. The expected negative effect of distance and the positive effect of the common border are declining towards the right tail of the distribution, i.e. their impact is weakening at higher levels of export. This conclusion confirms Novy's (2013) hypothesis about the asymmetry of the impact of trade costs, that is, their greater impact at lower levels of trade. To put it differently, by increasing export, countries become less sensitive to the growth of transportation costs that are embodied in distance and common border, which can be explained by economies of scale.

The export dynamics of both considered product categories is significantly influenced by the exchange rate, which is a particularly important result in the context of the research that is the subject of this paper. The analysed sectors react differently to exchange rate changes, and the impact also differs depending on the intensity of trade within these sectors.

The exchange rate volatility has a negative and statistically significant impact at all analysed levels of the export of the considered product categories. Unlike previous researches in which the impact of volatility on the export ranged from negative, through neutral, to positive, the results in this research clearly show that volatility negatively affects the export of differentiated products of the analysed CESEE countries. This finding is especially important bearing in mind that it was obtained by estimating the model in which the impact of unobserved factors that characterize trade between country pairs is controlled, which, as Tenreyro (2007) states, contributes to better identification of volatility impact. In addition to this, an important contribution to the discussion on the impact of volatility on export is the finding of a growing impact of volatility along the distribution of the export of differentiated products. Thus, Novy's (2013) hypothesis about the asymmetry of the impact of trade costs has not been confirmed in the case of exchange rate volatility. More specifically, following IMF (2004), the estimate of regression coefficients at the $10 \%$ quintile implies that an increase in volatility of one standard deviation $(0.0088$, i.e. $0.88 \%)$ would lead to $15.76 \%$ decrease in export when it comes to BEC 4 , or $17.62 \%$ when it comes to BEC 5, while the same exchange rate change on the $90 \%$ quintile 
would cause the decrease in export of BEC 4 by $19.37 \%$, and BEC 5 by $26.06 \%$. According to Rauch (1999), trade of differentiated products is characterized by the absence of close substitutes and the existence of search costs, resulting in greater sensitivity of differentiated products to exchange rate volatility. This provides a basis for explanation of the stronger impact of volatility at higher export levels. Namely, at higher levels of export of differentiated products we can expect pronounced intra-sectoral trade. Consequently, at higher levels of export search costs are also more pronounced, which, together with the lack of close substitutes, provides an explanation for strengthening the impact of exchange rate volatility at higher levels of export of products characterized by a high degree of technological and capital intensity.

In contrast to volatility, exchange rate misalignment statistically significantly affect only export of Capital goods (except transport equipment) and parts and accessories thereof, with the sign of the estimated regression coefficient being negative. Although a positive sign is expected (having in mind the approach used to calculate the exchange rate imbalance), the obtained finding indicates an important conclusion. Namely, the very fact that the exchange rate deviates from the equilibrium level can have negative effects on export, which can be explained on the basis of political economy theory, i.e. the potential spillover of exchange rate policy to foreign trade policy, as well as the possibility of the impact of changes in the level of exchange rate on the strengthening of protectionist activity. (Đorđević Zorić, 2019). Given that exchange rate policy is getting greater attention in debates on contemporary foreign trade policy, and that any deviation of the exchange rate from the equilibrium level may result in certain protectionist pressures, it is not surprising that certain sectors are sensitive to exchange rate misalignment, regardless of the direction of deviation of the exchange rate from the equilibrium level (Broz, 2010).

\section{Conclusions}

The research in this paper aimed to analyse the impact of exchange rates changes on the export of differentiated products in CESEE countries while controlling the impact of other factors that are usually included when international trade is analysed bilaterally. When considering the impact of changes in the environment (both local and global) and defining measures, economic policymakers of CESEE countries should take into account the specifics of response of export of highly processed products that bring higher export revenues, whose share in export these countries are trying to increase. Consequently, the findings obtained in this study have clear policy implications. 
Supply side and demand side factors, as well as the transportation costs (distance and common border) statistically significantly affect the export of differentiated products, at all considered levels. The intensity of the impact varies depending on the level of export, which is an important contribution to the previous researches that used to be based on the average impact.

Of particular importance is the result which shows that exchange rate changes significantly affect the export of differentiated products. For the analysed CESEE countries, exchange rate volatility is an important trade cost whose impact grows as the value of export increases. The proven negative impact of short-term exchange rate fluctuations on the export of differentiated products shows that reducing volatility would have a positive effect on increasing the export of high value-added products in the countries in this region, where export growth is the engine of overall economic growth. The growing impact of volatility towards higher levels of export suggests that reducing exchange rate volatility would stimulate larger exporters of the products with modern technological characteristics and higher value added, which is of particular importance for the countries of the analysed region.

Taking into account the impact of both analysed types of exchange rate changes, it can be concluded that volatility is a more dominant trade cost than misalignment. But, the stabilization of exchange rates around their equilibrium level is desirable to avoid protectionist pressures and sending wrong price signals that can lead to inadequate resource allocations and changes in investment decisions.

The obtained results indicate the need to find the ways to reduce the risk, uncertainty and transaction costs associated with exchange rate changes. Deeper countries' involvement in Global Value Chains (Ahmed, Appendino \& Ruta, 2015; Ollivaud, Rusticelli \& Schwellnus, 2015; IMF, 2019), invoicing international trade in third country currencies (IMF, 2019), and risk hedging are some of the recommendations for minimizing the harmful consequences of exchange rates changes.

\section{References}

Ahmed, S., Appendino, M., \& Ruta, M. (2015). Depreciations without Exports? Global Value Chains and the Exchange Rate Elasticity of Exports. Washington, DC: The World Bank.

Anderson, J. E., \& Van Wincoop, E. (2003). Gravity with gravitas: a solution to the border puzzle. American economic review, 93(1), 170-192. doi: 10.1257/000 2828 03321455214 
Aristotelous, K. (2001). Exchange-rate volatility, exchange-rate regime, and trade volume: evidence from the UK-US export function (1889-1999). Economics Letters, 72(1), 87-94. doi: 10.1016/S0165-1765(01)00414-1

Auboin, M., \& Ruta, M. (2013). The relationship between exchange rates and International Trade: A literature review. World Trade Review, 12(3), 577-605. doi:10.1017/S1474745613000025

Bailey M.J., Tavlas G.S. \& Obstfeld M. (1989). Trade and Investment under Floating Rates: The U.S. Experience. In J.A. Dorn \& W.A. Niskanen (Eds.), Dollars Deficits \& Trade (pp. 207-235). Springer, Dordrecht.

Baltagi, B. H., \& Egger, P. (2016). Estimation of structural gravity quantile regression models. Empirical Economics, 50(1), 5-15. doi: 10.1007/s00181-015-0956-5

Baron, D. P. (1976). Flexible exchange rates, forward markets, and the level of trade. The American Economic Review, 66(3), 253-266. Retrieved from www.jstor.org/stable/1828160

Berg, M. A., \& Miao, Y. (2010). The real exchange rate and growth revisited: The Washington Consensus strikes back? IMF Working Papers, 10(58), 1-24. doi: 10.5089/9781451963755.001

Bergstrand, J. (1985). The Gravity Equation in International Trade: Some Microeconomic Foundations and Empirical Evidence. The Review of Economics and Statistics, 67(3), 474-481. doi:10.2307/1925976

Bergstrand, J. H. (1989). The generalized gravity equation, monopolistic competition, and the factor-proportions theory in international trade. The review of economics and statistics, 71(1), 143-153. doi:10.2307/1928061

Bernard, A. B., \& Jensen, J. B. (2004). Entry, expansion, and intensity in the US export boom, 1987-1992. Review of International Economics, 12(4), 662-675. doi: 10.1111/j.1467-9396.2004.00473.x

Brada, J. C., \& Méndez, J. A. (1988). Exchange rate risk, exchange rate regime and the volume of international trade. Kyklos, 41(2), 263-280.

Brodsky, D. A. (1984). Fixed versus flexible exchange rates and the measurement of exchange rate instability. Journal of International Economics, 16(3-4), 295-306. doi: 10.1016/S0022-1996(84)80006-9

Broll, U., \& Eckwert, B. (1999). Exchange rate volatility and international trade. Southern Economic Journal, 66(1), 178-185. doi: 10.1016/0261-5606(91)90041-H

Broz, J. L. (2010, November). Exchange Rates and Protectionism. Manuscript, UCSD, Prepared for the fifth annual meeting of the International Political Economy Society (IPES), Weatherhead Center for International Affairs, Harvard University, Cambridge, MA. Retrieved frorm https://ucsd.edu/

Byrne, J. P., Darby, J., \& MacDonald, R. (2008). US trade and exchange rate volatility: A real sectoral bilateral analysis. Journal of macroeconomics, 30(1), 238-259. doi: 10.1016/j.jmacro.2006.08.002

Caglayan, M., \& Di, J. (2010). Does real exchange rate volatility affect sectoral trade flows? Southern Economic Journal, 77(2), 313-335. doi: 10.4284/sej. 2010. 77. 2.313

Canay, I. A. (2011). A simple approach to quantile regression for panel data. The Econometrics Journal, 14(3), 368-386. doi: 10.1111/j.1368-423X.2011.00349.x 
Chit, M. M., Rizov, M., \& Willenbockel, D. (2010). Exchange rate volatility and exports: new empirical evidence from the emerging East Asian Economies. The World Economy, 33(2), 239-263. doi: 10.1111/j.1467-9701.2009.01230.x

IMF (2004). Exchange rate volatility and trade flows-some new evidence. International Monetary Fund, Washington D.C.

Côté, A. (1994). Exchange rate volatility and trade (Work. Pap, 94-5). Bank of Canada

Cushman, D. O. (1983). The effects of real exchange rate risk on international trade. Journal of international Economics, 15(1-2), 45-63. doi: 10.1016/00221996(83)90041-7

De Grauwe, P., \& Verfaille, G. (1988). Exchange rate variability, misalignment, and the European monetary system. In R.C. Marston (Ed.), Misalignment of Exchange Rates: Effects on Trade and Industry (pp. 77-104). University of Chicago Press.

Égert, B., \& Morales-Zumaquero, A. (2008). Exchange rate regimes, foreign exchange volatility, and export performance in Central and Eastern Europe: Just another blur project? Review of Development Economics, 12(3), 577-593. doi: 10.1111/j.1467-9361.2008.00473.x

Ethier, W. (1973). International trade and the forward exchange market. The American Economic Review, 63(3), 494-503. Retrieved from www.jstor.org/stable/1914383

Fang, W., Lai, Y., \& Miller, S. M. (2009). Does exchange rate risk affect exports asymmetrically? Asian evidence. Journal of International Money and Finance, 28(2), 215-239. doi: 10.1016/j.jimonfin.2008.11.002

Figueiredo, E., Lima, L. R., \& Schaur, G. (2014, April). Robust estimation of gravity equations and the WTO impact on trade inequality. Paper prepared for the CESifo Conference on Estimation of Gravity Model of Bilateral Trade, Munich. Retrieved from https://www.cesifo.org/en

Franke, G. (1991). Exchange rate volatility and international trading strategy. Journal of International Money and Finance, 10(2), 292-307. doi: 10.1016/02615606(91)90041-H

Gagnon, J. E. (1993). Exchange rate variability and the level of international trade. Journal of International economics, 34(3), 269-287. doi: 10.1016/00221996(93)90050-8

Galvao Jr, A. F. (2011). Quantile regression for dynamic panel data with fixed effects. Journal of Econometrics, 164(1), 142-157. doi: 10.1016/j.jeconom.2011.02.016

Galvao, A. F., Lamarche, C., \& Lima, L. R. (2013). Estimation of censored quantile regression for panel data with fixed effects. Journal of the American Statistical Association, 108(503), 1075-1089. doi: 10.1080/01621459.2013.818002

Giovannini, A. (1988). Exchange rates and traded goods prices. Journal of international Economics, 24(1-2), 45-68. doi: 10.1016/0022-1996(88)90021-9

Hausmann, R., Pritchett, L., \& Rodrik, D. (2005). Growth accelerations. Journal of economic growth, 10(4), 303-329. doi: 10.1007/s10887-005-4712-0

Hooper, P., \& Kohlhagen, S. W. (1978). The effect of exchange rate uncertainty on the prices and volume of international trade. Journal of international Economics, 8(4), 483-511. doi: 10.1016/0022-1996(87)90001-8

IMF. (2019). External Sector Report: The Dynamics of External Adjustment. International Monetary Fund, Washington D.C: Author. 
Kasman, A., \& Kasman, S. (2005). Exchange rate uncertainty in Turkey and its impact on export volume. METU Studies in Development, 32(June), 41-58. Retrieved from http://www2.feas.metu.edu.tr/metusd/ojs/index.php/metusd

Kato, K., Galvao Jr, A. F., \& Montes-Rojas, G. V. (2012). Asymptotics for panel quantile regression models with individual effects. Journal of Econometrics, 170(1), 76-91. doi: 10.1016/j.jeconom.2012.02.007

Kenen, P., \& Rodrik, D. (1986). Measuring and Analyzing the Effects of Short-Term Volatility in Real Exchange Rates. The Review of Economics and Statistics, 68(2), 311-315. doi: 10.2307/1925511

Kočenda, E., \& Valachy, J. (2006). Exchange rate volatility and regime change: A Visegrad comparison. Journal of Comparative Economics, 34(4), 727-753. doi: 10.1016/j.jce.2006.07.003

Koenker, R. (2004). Quantile regression for longitudinal data. Journal of Multivariate Analysis, 91(1), 74-89. doi: 10.1016/j.jmva.2004.05.006

Kovačević, R. (2016). Međunarodne finansije. Beograd: Centar za izdavačku delatnost Ekonomskog fakulteta

Machado, J. A., \& Silva, J. S. (2019). Quantiles via moments. Journal of Econometrics, 213(1), 145-173. doi: 10.1016/j.jeconom.2019.04.009

Marini, M., Dippelsman, R., \& Stanger, M. (2018). New estimates for direction of trade statistics. IMF Working Papers, 18(16), 1-38. doi: 10.5089/9781484338629.001

Marino, M. F., \& Farcomeni, A. (2015). Linear quantile regression models for longitudinal experiments: an overview. Metron, 73(2), 229-247. doi: 10.1007/s40300-0150072-5

McKenzie, M. D. (1998). The impact of exchange rate volatility on Australian trade flows. Journal of International Financial Markets, Institutions and Money, 8(1), 21-38. doi: 10.1016/S1042-4431(98)00022-5

McKenzie, M. D., \& Brooks, R. D. (1997). The impact of exchange rate volatility on German-US trade flows. Journal of International Financial Markets, Institutions and Money, 7(1), 73-87. doi: 10.1016/S1042-4431(97)00012-7

Nicita, A. (2013). Exchange rates, international trade and trade policies. International Economics, 135, 47-61. doi: 10.1016/j.inteco.2013.10.003

Novy, D. (2013). International trade without CES: Estimating translog gravity. Journal of International Economics, 89(2), 271-282. doi: 10.1016/j.jinteco.2012.08.010

Ollivaud, P., Rusticelli, E., \& Schwellnus, C. (2015). The Changing Role of the Exchange Rate for Macroeconomic Adjustment. OECD Economics Department Working Papers, No. 1190, OECD Publishing, Paris. doi: 10.1787/5js4rfhjf15l-en

Paniagua, J., Figueiredo, E., \& Sapena, J. (2015). Quantile regression for the FDI gravity equation. Journal of Business Research, 68(7), 1512-1518. doi: 10.1016/j.jbusres.2015.01.043

Péridy, N. (2003). Exchange rate volatility, sectoral trade, and the aggregation bias. Review of World Economics, 139(3), 389-418. doi: 10.1007/BF02659668

Rauch, J. E. (1999). Networks versus markets in international trade. Journal of international Economics, 48(1), 7-35. doi: 10.1016/S0022-1996(98)00009-9

Razin, O., \& Collins, S. M. (1999). Real-Exchange-Rate Misalignments and Growth. In A. Razin \& E. Sadka (Eds.), The Economics of Globalization: Policy Perspectives from Public Economics (pp. 59-82). Cambridge: Cambridge University Press 
Rodrik, D. (2008). The real exchange rate and economic growth. Brookings papers on economic activity, 2008(2), 365-412. doi: 10.1353/eca.0.0020

Rose, A. K. (2000). One money, one market: the effect of common currencies on trade. Economic policy, 15(30), 08-45. doi: 10.1111/1468-0327.00056

Sercu, P., \& Vanhulle, C. (1992). Exchange rate volatility, international trade, and the value of exporting firms. Journal of banking \& finance, 16(1), 155-182. doi: 10.1016/0378-4266(92)90083-C

Staiger, R. W., \& Sykes, A. O. (2010). 'Currency manipulation'and world trade. World Trade Review, 9(4), 583-627. doi: 10.1017/S1474745610000340

Taglioni, D. (2002). Exchange rate volatility as a barrier to trade: new methodologies and recent evidence. Economie internationale, 2002/1(89-90), 227-259. Retrieved from https://www.cairn-int.info/\#

Tenreyro, S. (2007). On the trade impact of nominal exchange rate volatility. Journal of Development Economics, 82(2), 485-508. doi: 10.1016/j.jdeveco.2006.03.007

Wang, K. L., \& Barrett, C. B. (2007). Estimating the effects of exchange rate volatility on export volumes. Journal of Agricultural and Resource Economics, 32(2), 225-255. Retrieved from https://jareonline.org/

Wang, C., Wei, Y., \& Liu, X. (2010). Determinants of bilateral trade flows in OECD countries: evidence from gravity panel data models. The World Economy, 33(7), 894-915. doi: 10.1111/j.1467-9701.2009.01245.x

Đorđević Zorić, A. (2019). Neuravnoteženost deviznog kursa kao potencijalni okidač protekcionističke trgovinske politike. Ekonomske ideje i praksa, (34), 47-60. Retrieved from https://www.ekof.bg.ac.rs/publikacije/casopisi/ekonomske-ideje-ipraksa/

CEPII Databases Retrieved from http://www.cepii.fr/CEPII/en/welcome.asp

UN Comtrade Database Retrieved from https://comtrade.un.org/data/

IMF International Financial Statistics Database Retrieved from https://data.imf.org/ regular.aspx?key=61545850

IMF World Economic Outlook Databases Retrieved from https://www.imf.org/en/ Publications/SPROLLs/world-economic-outlookdatabases\#sort=\%40imfdate\%20descending

Penn World Table version 9.1 Retrieved from https://www.rug.nl/ggdc/productivity/pwt/ 